\title{
Laboratory tests on the integrated management of cotton leaf worm Spodoptera littoralis (Boisd.) by using some insecticides and entomopathogenic nematodes
}

\author{
Hassan, H. M. and Ibrahim, Sanaa, A. \\ Plant Protection Department, Faculty of Agriculture , Minia University \\ Corresponding author: dr_hassan_m_hassan2000@yahoo.com
}

\begin{abstract}
Effects of certain insecticides i.e. Coragen, Nomolt, Ekio and Magic smart with two species of entomopathogenic nematodes, Steinernama carpocapsae and Heterorhabdits bacteriophora were tested against cotton leaf worm Spodoptera littoralis. All tested insecticides caused less mortality to the tested entomopathogenic nematodes. Magic Smart significantly surpassed other insecticides causing the mortality of 11.6 and $13.8 \%$ to the entomopathogenic nematodes $S$. carpocapsae and H. bacteriophora opposite to Coragen that caused slight mortality, 2.5 and $4.4 \%$, respectively and didn't differ significantly than the check. Nomolt and Ekio gave mortality of 5.4 and $8.8 \%$ to $S$. carpocapsae as well as 8.8 and $12.0 \%$ to $H$. bacteriophora respectively. These results show that the used insecticides have less effect on entomopathogenic nematodes specially $S$. carpocapsae. The entomopathogenic nematode $S$. carpocapsae exposed to Coragen, Nomolt, Ekio and Magic smart gave 92.5, 85.0, 80.0 and75.0 \% mortality to cotton leaf worms $5^{\text {th }}$ larval instar, respectively. The entomopathogenic nematode H. bacteriophora exposed to Coragen ,Nomolt, Ekio and Magic smart gave 83.4, $77.2,71.0$ and $60.6 \%$ mortality \% of S. littoralis, respectively. Joint effect of insecticides and entomopathogenic nematodes show that the mixture between $S$. carpocapsae with each of Coragen, Nomolt, Ekio and Magic smart at the quarter lethal concentration $\left(\mathrm{LC}_{25 \mathrm{~s}}\right)$ per each gave synergism, synergism, additive and additive effects, respectively. As while $H$. bacteriophora mixed at the $\mathrm{LC}_{25}$ with the $\mathrm{LC}_{25}$ of Coragen, Nomolt, Ekio and Magic Smart attained synergism, additive, additive and additive effects, respectively.
\end{abstract}

Key words: Entomopathogenic nematodes, Co-toxicity, S.carpocapsae, H. bacteriophora

\section{Introduction}

Combination of biocides and chemical pesticides may be taken in consideration with any prospected integrated pest management program. The used combined factors in the IPM program must be chosen to sustain each other against the target pest with minimum effect on the other non -target organisms. In this regard synergistic or antagonistic effects between the entomopathogenic nematodes as biocides and pesticides used in combination had been studied by Rao et al. (1975), Hara and Kaya (1983), Qin (1984), Das and Divakar (1987), Ishibashi et al. (1987), Kaya and Burlando (1989), Rovesti et al. (1990), El-Kifl and Sammour (1991), Gaugler and Campell (1991), Hassan (1993), Mourad et al. (1994), Saleh and Sammour (1995), Peters. and Poullot (2004) Negrisoli Jr. et al. (2010) and Hassan (2016).

The present study was carried out to evaluate the combined effects of two entomopathogenic nematodes Steinernema carpocapsae and Heterorhabditis bacteriophora and four insecticides, Coragen, Nomolt, Ekio and Magic Smart against cotton leaf worm, Spodoptera littoralis (Boisd.).

\section{Materials and Methods}

The tested insects and entompathogenic nematodes:Insect rearing and entomopathogenic nematodes multiplication, as well as bioassays, were performed at Pesticide Researches Laboratory, Plant Protection Department, Faculty of Agricultural, Minia University
Greater wax moth larvae were produced in incubator at $28 \pm 2{ }^{\circ} \mathrm{C}, 60 \%$ relative humidity and $12 \mathrm{~h}$ photoperiod, according methodology modified by Parra (1998). Cotton leaf worms Spodoptera littoralis was reared in Plant Protection Department Laboratory, Faculty of Agriculture Minia University on castor leaves for several generations according to the method explained by Entompathogenic nematodes Heterorhabditis bacteriophora and Steinernema carpocapsae were obtained from Laboratory of Nematology, Faculty of Agriculture Cairo University and reared on Galleria mellonella for several generations in Zoology Research Laboratory, Plant Protection Department, Faculty of Agricultural, Minia University according to Kaya and Stock (1997). Infective juveniles of nematodes stored in incubator at $15{ }^{\circ} \mathrm{C}$ in plastic bottles arranged horizontally according to Hassan (2016)

\section{The tested insecticides:-}

The tested insecticides were Coragen (chlorantaniliprole) this insecticide stimulates the release of calcium in muscle cell cytoplasm causing the paralysis of muscles within 3-04 days after treatment. Other insecticides, Nomolt (teflubenzuron), Ekio (novaluron) and Magic Smart (lufenuron), act as chitin synthesis inhibitors preventing the formation of chitin in the new cuticle, make the new cuticle unable to persist the pressure of body fluids and muscle contractions during the molting process, so they called anti-molting compounds. 


\section{The effect of mixing entomopathogenic nematodes with insecticides:-}

Entomopathogenic nematodes at the concentration of $2500 \mathrm{IJs} / \mathrm{ml}$ (the field rate) with the tested insecticides with their field usage rate (Coragen $20 \%$ $\mathrm{SC}$ at $60 \mathrm{ml} / 400 \mathrm{~L}$., Nomolt 15\% SC 50ml / 100 L., Ekio 10\% EC $60 \mathrm{ml} / 100 \mathrm{~L}$. and Magic Smart 5\% EC at $160 \mathrm{ml} / 400 \mathrm{~L}$.$) ,) was applied for evaluating IJs$ viability and infectivity after being exposed to insecticides. According to methodology suggested by Negrisoli Jr. et al (2010)

One liter of each insecticide formulation was prepared proportionally to the double concentrations that would be normally applied in the field. From these solutions, $1 \mathrm{~mL}$ aliquots of each insecticide prepared solution were placed in glass test tube distilled and latter 2500 IJs per each nematode species contained in $1 \mathrm{~mL}$ of distilled water were added to the mentioned above tubes. Each tube represented one replicate from five. These tubes were held in incubator at $22 \pm 1 \mathrm{C}$; RH of $70 \pm 10 \%$ with $12 \mathrm{~h}$ photoperiod.

Nematode mortality was evaluated $48 \mathrm{~h}$ after their exposure to the insecticide. Thus $0.1 \mathrm{ml}$ from the suspension of each tube was removed to watch class and $100 \mathrm{IJs}$ were observed under the stereo microscope, considering dead those that don't reacted when touched with a probe. Mortality percentages were corrected according to Abbot' formula, Abbot (1925)

Nematode infectivity test were carried by filling the tubes of the previous test with $3 \mathrm{ml}$ of distilled water and placed to rest for $30 \mathrm{~min}$ in incubator at 15 C. Supernatant liquid (approximately $3 \mathrm{ml}$ ) was then withdrawn and rinsing process repeated for three times. After the last rinsing, a volume of $0.2 \mathrm{~mL}$ (approximately $400 \mathrm{IJs}$ ) were drawn from the bottom of each tube and distributed in five Petri dishes $(9 \mathrm{~cm}$ diameter) containing filter paper previously wetted with $1.8 \mathrm{ml}$ distilled water for each treatment with each Petry dish as one replicate. Each dish received ten fourth instar larvae of $S$. littoralis, kept in incubator at $22 \pm 1^{\circ} \mathrm{C}$ and R.H. of $70 \pm 10 \%$ with $12 \mathrm{~h}$ photoperiod for five days. Dead larvae were counted, transferred to Petri dishes ( $9 \mathrm{~cm}$ diameter) containing dry filter paper and maintained into darkness for more three days. Finally they were dissected to verify nematode' presence (Negrisoli Jr. et al., 2010). The experiment's statistical design was completely random.

\section{Data analysis:}

Nematodes and cotton leaf worm mortality data were subjected to variance analysis and differences between treatment means were estimated by Chi square test at 0.05 probability. The effect of the treatments on nematodes infectivity over S. littoralis larvae was classified according Peters and Poullot (2004), based on IOBC guideline

$\mathrm{E} \%=1-(\mathrm{It} / \mathrm{Ic}) \mathrm{x} 100$

$\mathrm{It}=$ mortality in treatment
Ic $=$ mortality in control treatment

Classification of insecticides effect on nematodes infectivity

$1=$ non effect $(\mathrm{E}<30 \%) \quad 2=$ slightly effect $(\mathrm{E}=30$ 79\%) $3=$ moderately effect $\mathrm{E}>79$

\section{Combined effect of nematodes and insecticides:-}

To determine the combined effect of nematodes and insecticides mixtures of insecticides and nematodes at the concentration of LC 25 for each were applied against $S$. littoralis $5^{\text {th }}$ larval instar and mortality percentages were estimated

Estimation of LC25 of nematodes was by testing seven concentrations of 2000, 5000, 10000, 20000, 30000, 40000 and 50000 infective juveniles (IJs) of each $H$. bacteriophora and $S$. carpocaopsae nematodes / liter were prepared in distilled water. One $\mathrm{ml}$ of nematode suspension of each concentration was dispersed on five larvae of $S$. littolaris $\left(5^{\text {th }}\right.$ instar) supplied with piece of castor leaf in Petri dishes $15 \mathrm{~cm}$ in diameter.

As for insecticides different concentrations of each insecticide were tested. Mortality of larvae by nematodes or insecticides was corrected by Abbot's formula (1925). LC $25 \mathrm{~s}$ were estimated according to Finney (1971).

Mixtures of insecticides and nematodes at the concentration of $\mathrm{LC}_{25}$ for each were prepared. One $\mathrm{ml}$ of each mixture was applied on larvae supplied with castor leaf in Petri dishes. Each treatment was replicated four times. Average of mortality was estimated and corrected with control treatment. Cotoxicity factor (C.F.) was determined according to Mansour et al (1966) as follows: (Observed mortality - Expected mortality / \% Expected mortality) $\times 100$.

A positive C.F. value of 20 or more was considered synergism. Negative value of 20 or more was considered antagonism. Any value lies between 20 and +20 was taken as an additive effect

\section{Results and Discussion}

Data in Table 1 show that Magic was the insecticide that significantly surpassed others causing the highest mortality $11.6 \%$ to Steinernema carpocapsae opposite to Coragen that caused less mortality to this nematode and didn't differ significantly than the check. Nomolt and Ekio gave mortality of 5.4 and $8.8 \%$ to $S$. carpocapsae, respectively. These results show that the used insecticides specially Coragen have less effect on entomopathogenic nematodes specially $S$. carpocapsae. Entomopathogenic nematodes are often applied to sites and ecosystems that routinely receive other inputs that may interact with nematodes including chemical pesticides, surfactants, fertilizers and soil amendments. Often it is desirable to tank mix one or more inputs to save time and money. Infective juveniles are tolerant of short exposures (2-6 h) to most agrochemicals including herbicides, fungicides, 
acaricides and insecticides (Rovesti and Deseo, 1990; Ishibashi and Takii, 1993) and therefore, can often be tank-mixed.

Steinernematid and heterorhabditid nematodes can survive exposure to many chemical pesticides (Hara and Kaya, 1982; Rovesti and Deseo, 1990; Rovesti et al., 1989). However, infective juveniles are highly susceptible to several nematicides likely to be found in the agroecosystem (Rovesti and Deseo, 1990, 1991).

Glazer et al. (1997) examined genetic selection as a means of enhancing resistance of $H$. bacteriophora strain HP88 to the nematicides: fenamiphos (organophosphate), oxamyl (carbamate) and averrmectin (biologically- derived product). After 11 rounds of selection, resistance to the nematicides as well as several traits relevant to bio-control efficacy including virulence, heat tolerance, and reproduction potential were examined

Data tabulated in Table 2 display the mortality percentages of Spodoptera littoralis treated by $S$. carpocapsae previously mixed with different insecticides i.e. Coragen, Nomolt, Ekio or Magic.

The entomopathogenic nematode $S$. carpocapsae exposed to Coragen gave high mortality to $S$. littoralis $(92.5 \%)$ and didn't significantly differ than check treatment ( $S$. carpocapsae unexposed to insecticides) that caused $95 \%$ mortality to $S$. littoralis and the treatment effect (E, value) was 2.6 that mean non effect of this insecticide on $S$. carpocapsae infectivity. This nematodes exposed to Nomolt gave $85 \%$ mortality and E, value 10.5 . Ekio caused moderated loss of infectivity of $S$. carpocapsae ( $80 \%$ mortality of cotton leaf worms) when compared with control (95\% mortality of cotton leaf worms). On the other hand nematodes exposed to Magic smart significantly differed with other insecticides and check treatment that caused less mortality $75 \%$ to $S$. littoralis and treatment effect value was 23.7 that still in the range of non-effect on nematode infectivity.

Rovesti and Deseo (1990) observed that Chitin synthesis inhibitors didn't affected $S$. carpocapsae viability. These insecticides didn't cause noticeable inhibition in reproduction and development of $S$. carpocapsae (Hara and kaya, 1982, 1983)

Data in Table 3 show that Magic Smart as was the insecticide that significantly surpassed others causing the highest mortality of $S$. carpocapsae it also gave highest mortality $13.8 \%$ to Heterorhabditis bacteriophora opposite to Coragen that caused less mortality to this nematode (4.4\%) and didn't differ significantly than the check. Nomolt and Ekio gave mortality of 8.8 and $12.0 \%$ to H. bacteriophora, respectively. On the other hand these results show that $H$. bacteriophora tend to be more sensitive to the tested insecticides than S. carpocapsae. Gaugler 2002 mentioned that heterorhabditis are more sensitive to chemical challenges, including pesticides, than steinernematids.

Table 4 explains that the entomopathogenic nematode $H$. bacteriophora exposed to Coragen gave high mortality to $S$. littoralis $(83.4 \%)$ but significantly was low than the check $(96.0 \%)$ and the estimated treatment effect of insecticide on nematode infectivity (E, value) was 13.1 (non-effect). This nematode exposed to Nomolt gave $77.2 \%$ mortality of $S$. littoralis and E value 19.6 (Non-effect). Ekio caused moderated loss of infectivity of $H$. bacteriophora (71.0\% mortality of S. littoralis) with E, value of 26.0 (non-effect on nematode infectivity). On the other hand $H$. bacteriophora exposed to Magic smart significantly caused less mortality $60.6 \%$ to $S$. littoralis. The estimated treatment effect of Magic smart on $H$. bacteriophora infectivity on S. littoralis was 37.5 that mean slightly effect of Magic smart on H. bacteriophora infectivity.

Table 5 explains propit data established from toxicity line equations of tested entomopathogenic nematodes on $S$. littoralis $5^{\text {th }}$ larval instar the estimated LC50s of Coragen, Nomolt, Ekio and Magic smart were 234.72, 3.88, 19.84 and $13.98 \mathrm{mg} / 1$. while the $\mathrm{LC}_{25}$ values were $11.84,0.61,5.00$ and $3.91 \mathrm{mg} /$ 1. for these insecticides, respectively. On the other hand the estimated $\mathrm{LC}_{50 \text { s }}$ of S.carpocapsae and $H$. bacteriophora were 27531 and 19780 infective juveniles per liter (IJs), while the $\mathrm{LC}_{25 \mathrm{~s}}$ for these nematodes were 6003 and 4343 IJs, respectively

Data in Table 6 show the co-toxicity of the tested insecticides and entomopathogenic nematodes. The mixture of S. carpocapsae at the LC25 with the LC25 of Coragen, Nomolt, Ekio or Magic Smart attained cotoxicity coefficients $+30,+20,+10$ and -10 , respectively. These results mean that the effects of these mixtures gave synergism, synergism, additive and additive actions, respectively. On the other hand the mixture of $H$. bacteriophora at LC25 with the LC25 of Coragen, Nomolt, Ekio or Magic Smart recorded co-toxicity coefficients $+20,+10,-10$ and 16 , respectively. So these trial effects were synergism, additive, additive and additive, respectively.

Table 1. Effect of certain insecticides on the mortality of Steinernema carpocapsae at $22 \pm 1^{\circ} \mathrm{C}$ and $\mathrm{RH} 70 \pm 10 \%$

\begin{tabular}{ll}
\hline Treatment & Mortality $\%$ \\
\hline Control (only distilled water) & $0.0 \mathrm{c}$ \\
\hline Coragen & $2.5 \mathrm{c}$ \\
\hline Nomolt & $5.4 \mathrm{abc}$ \\
\hline Ekio & $8.8 \mathrm{ab}$ \\
\hline Magic Smart & $11.6 \mathrm{a}$ \\
\hline 1-Mortality percentages were corrected according to Abbot's formula & \\
2-Mortalities followed by the same litters didn't significantly differ according to Chi square test.
\end{tabular}


Table 2. Effect of certain insecticides on the infectivity (average \pm SE) of Steinernema carpocapsae measured by Spodoptera littoralis $5^{\text {th }}$ larval instar mortality at $22 \pm 1^{\circ} \mathrm{C}$ and $\mathrm{RH} 70 \pm 10 \%$

\begin{tabular}{llll}
\hline Treatment & $\%$ mortality of cotton leaf worms & Treatment effect (E\%) & Effect classification \\
\hline Control & $95.0 \mathrm{a}$ & - & - \\
\hline Coragen & $92.5 \mathrm{a}$ & 2.6 & 1 \\
\hline Nomolt & $85.0 \mathrm{~b}$ & 10.5 & 1 \\
\hline Ekio & $80.0 \mathrm{bc}$ & 15.8 & 1 \\
\hline Magic & $72.5 \mathrm{c}$ & 23.7 & 1 \\
\hline
\end{tabular}

1- Mortalities followed by the same litters didn't significantly differ according to Chi square test.

$2-\mathrm{E} \%=1-(\mathrm{It} / \mathrm{Ic}) \times 100 \quad \mathrm{It}=$ mortality in treatment $\mathrm{Ic}=$ mortality in control treatment

Classification of insecticides effect on nematodes infectivity

$1=$ non effect $(\mathrm{E}<30 \%) \quad 2=$ slightly effect $(\mathrm{E}=30-79 \%) \quad 3=$ moderately effect $\mathrm{E}>79$

Table 3. Effect of certain insecticides on the mortality of Heterorhabditis bacteriophora at $22 \pm 1^{\circ} \mathrm{C}$ and $\mathrm{RH} 70 \pm$ $10 \%$

\begin{tabular}{ll}
\hline Treatment & Mortality $\%$ \\
\hline $\begin{array}{l}\text { Control (Nematodes didn't exposed to insecticides) } \\
\text { only distilled water) }\end{array}$ & $0.0 * \mathrm{c}$ \\
\hline Nematodes exposed to Coragen & $4.4 \mathrm{bc}$ \\
\hline Nematodes exposed to Nomolt & $8.8 \mathrm{abc}$ \\
\hline Nematodes exposed to Ekio & $12.0 \mathrm{ab}$ \\
\hline Nematodes exposed to Magic & $13.8 \mathrm{a}$ \\
\hline 1-Mortality percentages were corrected according to Abbot's formula &
\end{tabular}

Table 4. Effect of certain insecticides on the infectivity of Heterorhabditis bacteriophora measured by Spodoptera littoralis $4^{\text {th }}$ larval instar mortality at $22 \pm 1^{\circ} \mathrm{C}$ and $\mathrm{RH} 70 \pm 10 \%$

\begin{tabular}{llll}
\hline Treatment & $\%$ mortality & Treatment effect $(\mathrm{E} \%)$ & Toxicity classification \\
\hline Control & 96.0 & - & - \\
\hline Coragen & 83.4 & 13.1 & 1 \\
\hline Nomolt & 77.2 & 19.6 & 1 \\
\hline Ekio & 71.0 & 26.0 & 1 \\
\hline Magic & 60.6 & 37.5 & 2 \\
\hline
\end{tabular}

1-Mortalities followed by the same litters didn't significantly differ according to Chi square test.

$2-\mathrm{E} \%=1-(\mathrm{It} / \mathrm{Ic}) \times 100$

$\mathrm{It}=$ mortality in treatment

$\mathrm{Ic}=$ mortality in control treatment

Classification of insecticides effect on nematodes infectivity

$1=$ non effect $(\mathrm{E}<30 \%) \quad 2=$ slightly effect $(\mathrm{E}=30-79 \%) \quad 3=$ moderately effect $\mathrm{E}>79$

Table 5. Probit data established from toxicity line equations of tested insecticides and entompathogenic nematodes on $S$. littoralis $5^{\text {th }}$ larval instar

\begin{tabular}{llllll}
\hline Treatments & Toxicity line equation & Slope & D.F. & LC $_{50}$ & LC $_{25}$ \\
\hline $\begin{array}{l}\text { Coragen } \\
\text { (chlorantraniliprole) }\end{array}$ & $\mathrm{Y}=2.0946+2.0821$ & 2.0946 & 3 & $24.72 \mathrm{mg} / 1$. & 11.84 \\
\hline $\begin{array}{l}\text { Nomolt } \\
\text { (teflubenzuron) }\end{array}$ & $\mathrm{Y}=0.8311 \mathrm{X}+4.5101$ & 0.8311 & 6 & $3.88 \mathrm{mg} / 1$. & 0.61 \\
\hline $\begin{array}{l}\text { Ekio } \\
\text { (novaluron) }\end{array}$ & $\mathrm{Y}=1.1205 \mathrm{X}+3.546$ & 1.1205 & 4 & $19.84 \mathrm{mg} / 1$. & 5.00 \\
\hline $\begin{array}{l}\text { Magic smatrt } \\
\text { (Lufenuron) }\end{array}$ & $\mathrm{Y}=1.2103 \mathrm{X}+3.6137$ & 1.2103 & 7 & $13.98 \mathrm{mg} / \mathrm{l}$. & 3.91 \\
\hline S. carpocapsae & $\mathrm{Y}=1.0129 \mathrm{X}+0.5029$ & 1.0129 & 5 & $27531.0 \mathrm{IJs} / 1$. & $6003.0 \mathrm{IJs} / 1$. \\
\hline H. bacteriophora & $\mathrm{Y}=1.0175 \mathrm{X}+0.6286$ & 1.0175 & 5 & $19780.0 \mathrm{IJs} / 1$. & $4343.0 \mathrm{IJs} / 1$. \\
\hline
\end{tabular}


Table 6. The combined effect of Steinernema carpocapsae mixtures with certain insecticides on S. litoralis $5^{\text {th }}$ instar larvae under laboratory conditions

\begin{tabular}{|c|c|c|c|c|}
\hline \multirow{2}{*}{$\begin{array}{l}\text { Mixtures } \\
\text { (Nematode }+ \text { insecticide) }\end{array}$} & \multirow{2}{*}{$\begin{array}{l}\mathrm{LC}_{25}+\mathrm{LC}_{25} \\
\text { IJs / liter + mg / } 1 .\end{array}$} & \multicolumn{3}{|c|}{ Mortality \% } \\
\hline & & Expected & Observed & $\begin{array}{l}\text { Co-toxicity } \\
\text { coefficient }\end{array}$ \\
\hline S. carpocapsae + Coragen & $6003.0+11.84$ & 50 & 65 & +30 Synergism \\
\hline S. carpocapsae + Nomolt & $6003.0+0.61$ & 50 & 60 & +20 Synergism \\
\hline S. carpocapsae + Ekio & $6003.0+5.00$ & 50 & 55 & +10 additive \\
\hline S. carpocapsae + Magic smart & $6003.0+3.91$ & 50 & 45 & -10 additive \\
\hline H. bacteriophora+ Coragen & $4343.0+11.84$ & 50 & 60 & +20 synergism \\
\hline H. bacteriophora+ Nomolt & $4343.0+0.61$ & 50 & 55 & +10 additive \\
\hline H. bacteriophora+ Ekio & $4343.0+5.00$ & 50 & 45 & -10 additive \\
\hline H. bacteriophora+ Magic smart & $4343.0+3.91$ & 50 & 42 & -16 additive \\
\hline
\end{tabular}

\section{Conclusion}

Based on the present study the compatibility of the insecticides, Coragen, Nomolt, Ekio and Magic Smart with the entomopathogenic nematodes, $S$. carpocapsae and $H$. bacteriophora at the LC25 for each may be possible and resulting synergism or additive effects than using each alone against cotton leaf worm.

\section{Acknowledgement}

This study was performed in Department of Plant Protection, Faculty of Agriculture, Minia University

\section{References}

Abbott, W.S. (1925). Amethod for computing the effectiveness of insecticides. J. Econ. Entomol. 18: 265-267.

Das, J. N. and Divakar, B. J. (1987). Compatibility of certain pesticides with DD- 136 nematode. P1.Prot. Bull. (India) 39: 20-22.

El-Kifl, T. A. H. and Sammour, E. A. (1991). Possible use of the endoparasitic nematode Neoaplectana carpocapsae (Weiser) combined with the insecticide hostathion for controlling the cutworm, Agrotis ipsilon (Hufn.). Entomol. Soc. Egypt. 17:215-223.

Finney, D. J. (1971). Probit analysis. $3^{\text {rd }}$ ed., Cambridge University Press, 333 pp.

Gaugler, R. (2002). Entomopathogenic Nematology, CABI Publishing, 388 pp.

Gaugler, R. and Campbell, J. F. (1991). Behavioral response of the entomopathogenic nematodes Steinernema carpocapsae and Heterorhabditis bacteriophora to Oxamyl. Ann. Appl. Biol., 119:131-138.

Glazer, I.; Salame, L. and Segal, D. (1997). Genetic enhancement of nematicidal resistance of entomopathogenic nematodes. Biocontrol Science and Technology 7: 499-512.

Hara, A. H. and Kaya, H. K. (1982). Effect of selected insecticides and nematicides on the in vitro development of entomogenous nematode Neoaplectana carpocapsae (Rhabditida:
Steinernematidae). Journal of Entomology 14 (4): 486-491.

Hara, A. H. and Kaya, H. K. (1983). Toxicity of selected organophosphate and carbamate pesticides to infective juveniles of the entomogenous nematode Neoaplectana carpocapsae (Rhabditida: Steinernematidae). Environmental Entomology 12, 496-501.

Hassan, H. M. (1993). Laboratory tests on the effect of Steinernema carpocapsae A11 strain and Heterorhabditis bacteriophora NC strain and their mixtures with Biomneem and Dipel on Spodoptera littoralis (Boisd.), J. Egypt. Ger. Soc.. Zool., 12:239-251.

Hassan, H. M. (2016). Effect of some factors on viability and bio-insecticidal potency of the entomopathogenic nematodes. $3^{\text {rd }}$ International Conference on Biotechnology Applications in Agriculture (ICBAA), Benha University, Moshtohor and Sharm EL-Sheikh, 5-9 April 2016, Egypt, Annals of Agriculture Science, Moshtohor, Special Issue, Bio-Pesticides techniques, 9-12.

Ishibashi, N.; Choi, D.R. and Kando, G. (1987). Integrated control of insects/nematodes by mixing application of steinernematid nematodes and chemicals. J. Nematol., 19:531-532.

Ishibashi, N. and Takii, S. (1993). Effects of insecticides on movement, nictation and infectivity of Steinernema carpoccapsae. J. Nematol., 25 (2): 204- 213.

Kaya, H. K. and Burlando, T. M. (1989). Infectivity of Steinernema feltiae in fenamiphose-treated sand. J. Nematol., 21:434-436.

Kaya, H. K. and Stock, S.P. (1997). Techniques in insect nematology. In : Lacey, L. A. (Ed.), Manual of Techniques in Insect Pathology. Academic Press, San Diego, California, pp. 281-324.

Mansour, N. A. ; Eldefrawi, M. E.; Tappozada, A. and Zaid, M. (1966). Toxicological studies on the cotton leafworm, Prodina litura. VI. Potential and antagonism of organophosphorus and carbamate insecticides. J. Econ. Entomol., 56: 307-311.

Mourad, M. G. ; Hassan, H. M.; Ali, M. A. and Abdel Raheem, W. A. (1994). Preliminary studies on the compatibility of some pesticides and 
entomogenous nematodes against Spodoptera littoralis (Boisd.) larvae. Minia J. Agric. Res. \& Dev., 16 (3):675-685.

Negrisoli Jr. A.S; Garcia, M. S. and Barbosa, C. R. C. (2010). Barbosa, C.R.C. and Moino Jr. A. (2008): Compatibility of entomopathogenic nematodes (Nematoda: Rhabditida) with registered insecticides for Spodoptera frugiperda (Smith, 1997) (Lepidoptera: Noctuidae) under laboratory conditions. Crop Protection 29: 545549.

Parra, J. R. P. (1998). Criacao de insetos para estudos com patogenos. In: Alves, S. B. (Ed.), Controle microbiano de insetos. FEALQ Piracicaba, pp. 1015-1038.

Peters, A. and Poullot, D. (2004). Side effects of surfactants and pesticides on entomopathogenic nematodes assessed using advanced IOBC guidelines. IOBC/WPRS Bulletin 27 (6): 67-72.

Qin, J. G. (1984). On the susceptibility of the nematode DD-136 to some chemicals. Nat. Enemies Insect, 6: 46-48.

Rao, P. S. P.; Das, P.K. and Pahdi, G. (1975). Note on compatibility of DD-136 Neoaplectana carpocapsae an insect parasitic nematode with some insecticides and fertilizers. Indian J. Agric. Sci., 45: 275-277.

Rovesti, L. and Deseo, K. V. (1990). Compatibility of chemical pesticides with the entomopathogenic nematodes, Steinernema carpocapsae Weiser and S. feltiae Filipjev (Nematoda: Steinernematidae). Nematologica 36, 237-245.

Rovesti, L. and Deseo, K. V. (1991). Compatibility of pesticides with the entomopathogenic nematode, Heterorhabditis heliothidis. Nematologica 37:113-116.

Rovesti, L.; Tagliente, F.; Deseo, K. V. and Heinzpeter, E. W. (1989). Compatibility of pesticides with the entomopathogenic nematode Heterorhabditis bacteriophora Poinar (Nematoda: Heterorhabditidae). Nematologica 34: 462-476.

Saleh, M. M. E.. and Sammour, E. A. (1995). Interactions of three insecticides and two entomopathogenic nematodes against Spodoptera littoralis (Boisd) larvae. Egyptian Journal Biological Pest Control, 5 (2): 119-122.

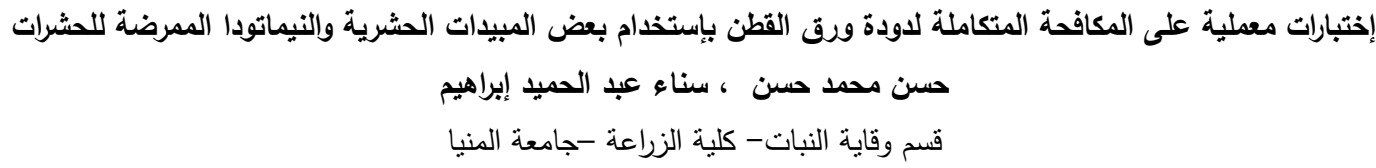

